International Journal of Agriculture, Environment and Bioresearch

Vol. 5, No. 06; 2020

ISSN: $2456-8643$

\title{
PERCEIVED NUTRITIONAL AND MEDICINAL BENEFITS OF COCOYAM AMONG RURAL DWELLERS IN KWARA STATE, NIGERIA
}

\author{
Olooto, Felicia Motunrayo \\ Department of Agricultural Economics and Extension Services, Kwara State University, Malete Nigeria \\ https://doi.org/10.35410/IJAEB.2020.5592
}

\begin{abstract}
The study investigated rural dwellers perception of the nutritional and medicinal benefits of cocoyam in Kwara State Nigeria. Three stage sampling technique was used to select 120 respondents for this study. Objectives of the study were to determine the level of cocoyam consumption among rural dwellers and to evaluate rural dwellers perception on the nutritional and medicinal benefits of cocoyam. Descriptive statistics such as mean, frequency counts, percentages and tables were used to analyze the results of the study. Results revealed that $43.3 \%$ of respondents are farmers and $34.2 \%$ of them belong to one farmers' group or the other. Majority $(91.7 \%)$ of respondents consume cocoyam which they usually obtained through growing (55\%), buying (35.8\%) and gift (9.2\%). The result also showed high percentage (83.3\%) of the respondents were aware of the nutritional and medicinal benefits of the consumption of cocoyam. Result showed that respondents perceived the following benefits can be derived from cocoyam: good for people with diabetes (Mean score $(\bar{x})=2.55$ ), reduce blood sugar $(\bar{x}=2.52)$, prevent heart problems $\left(\bar{x}^{-}=2.56\right)$ and reduce blood pressure $\left(\bar{x}^{-}=2.71\right)$. The study concluded that though the respondents are aware of the nutritional and medicinal benefits of consumption of cocoyam, there is need for more enlightenment on the level of consumption for various categories of health and nutritional status within households. It was therefore recommended that enlightenment programmes on the consumption of cocoyam should be carried out to ensure that the benefits are efficiently derived.
\end{abstract}

Keywords: Cocoyam, Health benefits, Nutritional benefits, Enlightenment programme, Cocoyam consumption.

\section{INTRODUCTION}

Cocoyam are herbaceous perennial plant belonging to the family aracieae and are grown primarily for their edible roots, although all parts of the plant are edible, cocoyam that are cultivated as food crop belongs to either the genus colocasiaor the genus xanthosomaand are generally comprised of a large spherical corm (swollen underground storage stem), from which a few large leaves emerges. Across the world, many plant species that are cultivated for food are neglected and underutilized despite having a crucial role in food security, nutrition and income generation of the rural poor (Magbagbeola et al 2010 and Barbieri et al 2014). Taro (Colocasiaesculenta) and new cocoyam or tannia (Xanthosomamafaffa) are two of these species and are the most important food crops in family Araceae. 
The petioles of the leaves stand erect and can reach lengths in excess of $1 \mathrm{~m}(3.3 \mathrm{ft})$, the leaves blade are large and heart -shaped and can reach $50 \mathrm{~cm}$ (15.8inches) in length. The corm produces lateral buds which give rise to tubers or corms and sucker or stolon. Xanthosoma species are also vegetatively propagated, usually from the sets, corm, piece, tuber or sucker, and require temperature above $21^{\circ} \mathrm{c}(69.8 \mathrm{f})$ to grow properly. Unlike colocasiaspp, they will not tolerate water logging and grow best in deep, well drain loams with a $\mathrm{P}^{\mathrm{H}}$ between 5.5 and 6.5 in partial shade. Xanthosoma specie is usually grown in ridges at the onset of the wet season.

The young leaves of taro are eaten as vegetable and are an important source of folic acid, vitamin A, vitamin C, riboflavin and minerals such as iron. Roots (corms) are consumed boiled, roasted or fried and are an important source of carbohydrates while the corn flour has been reported to have 70-80\% starch content with small granules, which results in high digestibility (Jane et al, 1992 cited in Bammiteet al 2018). As reported by Darkwa and Darkwa (2013)cake and chips prepared from a combination of taro flour and cereals such as maize/corn, rice and wheat are well accepted by Ghanaian people. Also, according to Bamideleet al. (2014) coprocessing of cassava and taro improved the nutritional quality of gari, a traditional cassava food product that is often eaten in West Africa. Another study by Igbabulet al. (2014), revealed that fermentation of taro corms before flourextraction helps to increase nutrients, reduce antinutritional factors, improve functional properties and enhance utilization of taro flour in different food systems.

Cocoyam (colocasiaspp and xanthosomaspp) is grown in the tropics and sub-tropical regions of the world particularly in Africa for human nutrition and medicinal value, animal feed, and cash income for both farmers and traders. In other parts of the world, species of Colocasia are often referred to as taro, while cocoyam or tannia is used for species of Xanthosoma (Manner \&Taylor, 2010; Lebot, 2009). As food for human consumption, the nutritional and medicinal value of the various part of cocoyam is primarily caloric (Davies et al, 2008). The underground corms provide easily digested starch; and the leaves are nutritious spinach like vegetables, which gives lot of minerals, vitamins and thiamine (Ezeet al, 2016).

Despite the nutritional advantages of cocoyam and its potential for poverty alleviation, relatively little research attention has been devoted to it. Consequently, the potentials of cocoyam as an important staple food crop and its associated nutritional and health advantages remain under-exploited. It has been noted that the situation of marginalized or under-researched crops such as cocoyam, which nevertheless are undoubtedly important to food and income security for millions of resource-limited farm households, will continue to worsen due to neglect and limited competitiveness unless steps are taken to raise their profile.

\section{OBJECTIVES OF THE STUDY}

The aim of the study was to investigate the perceived nutritional and medicinal benefits of consuming cocoyam among rural dwellers in Kwara State. The specific objectives were to;

- determine the level of consumption of cocoyam among rural dwellers in Kwara state.

- $\quad$ evaluate the perception of rural dwellers on the nutritional and medicinal benefits of cocoyam. 


\section{METHODOLOGY}

Study area: This study was carried out in Kwara State; Kwara State is located within the north central geopolitical zone, commonly referred to as middle belt region of Nigeria. The state is bounded by Niger and Kebbi States in the northern part, Kogi State in the East and Osun, Oyo and Ondo State in the South and Republic of Benin in the West. The State lies between latitudes $7^{0} 45 \mathrm{~N}$ and $9^{0} 30 \mathrm{~N}$ and longitudes $2^{0} 30 \mathrm{E}$ and $6^{0} 25 \mathrm{E}$. It is positioned in the forest savanna and enjoys reasonable dry and wet seasons, rainy season starts in April and ends in November, with heavier rains falling in September and October. This is a summer rainfall area, with an annual rainfall range of $1000 \mathrm{~mm}$ to $1,500 \mathrm{~mm}$. The month of December and January coincide with the cold and dry harmattan season. Average maximum temperatures vary between $30^{\circ} \mathrm{c}$ and $35^{\circ} \mathrm{c}$.

The capital city of Ilorin is situated 306km inland from the coastal city of Lagos and 500km from the federal capital, Abuja. Kwara state was created in May 1967, as one of the first 12 states to replace the nation's four regions. The soil is fertile and the state is well watered by the various tributaries of the Niger River which runs through hills and valleys.

Sampling procedure and sample size: The population of the study consists of all rural dwellers in the study area. A purposive sampling technique was adopted in the selection of the rural dwellers in the study area. One rural Local Government Area was selected from each of the three senatorial districts in Kwara state (Kwara South, Kwara North and Kwara Central). From each of the three local governments (Ifelodun, Ilorin west and Moro), one (1) rural community each was selected. Finally 40 rural dwellers were selected for the study from each community bringing the sample size to one hundred and twenty (120) rural dwellers that were interviewed for the study. Data for this study was obtained through the use of structured interview schedule used to solicit information from the respondents.

\section{RESULTS AND DISCUSSION}

Table 1: Level of respondents' consumption of cocoyam

\begin{tabular}{|l|l|l|l|l|l|l|}
\hline $\begin{array}{l}\text { Type/form } \\
\text { of cocoyam } \\
\text { consumed }\end{array}$ & Everyday & $\begin{array}{l}\text { Three times } \\
\text { a week }\end{array}$ & $\begin{array}{l}\text { Twice a } \\
\text { week }\end{array}$ & $\begin{array}{l}\text { Once a } \\
\text { week }\end{array}$ & $\begin{array}{l}\text { Not at } \\
\text { all }\end{array}$ & $\begin{array}{l}\text { Mean } \\
\text { Score }(\bar{x})\end{array}$ \\
\hline $\begin{array}{l}\text { Fried } \\
\text { cocoyam }\end{array}$ & $\begin{array}{l}14 \\
(11.7)\end{array}$ & $\begin{array}{l}30 \\
(25)\end{array}$ & $\begin{array}{l}12 \\
(10)\end{array}$ & $\begin{array}{l}41 \\
(34.2)\end{array}$ & $\begin{array}{l}23 \\
(19.2)\end{array}$ & 2.7583 \\
\hline $\begin{array}{l}\text { Pounded } \\
\text { cocoyam }\end{array}$ & $\begin{array}{l}55 \\
(45.8)\end{array}$ & $\begin{array}{l}50 \\
(41.7)\end{array}$ & $\begin{array}{l}12 \\
(10)\end{array}$ & 3 & - & 3.9917 \\
\hline $\begin{array}{l}\text { Cocoyam } \\
\text { flour }\end{array}$ & 59 & 31 & 15 & 13 & 2 & 4.1 \\
$(49.2)$ & $(25.8)$ & $(12.5)$ & $(10.8)$ & $(1.7)$ & \\
\hline Cocoyam & 55 & 50 & 12 & 3 & - & 4.3083 \\
\hline
\end{tabular}


Vol. 5, No. 06; 2020

ISSN: $2456-8643$

\begin{tabular}{|c|c|c|c|c|c|c|}
\hline porridge & (45.8) & (41.7) & (10) & (2.5) & & \\
\hline $\begin{array}{l}\text { Cocoyam } \\
\text { soup }\end{array}$ & $\begin{array}{l}90 \\
(80)\end{array}$ & $\begin{array}{l}18 \\
(15)\end{array}$ & $\begin{array}{l}2 \\
(1.7)\end{array}$ & $\begin{array}{l}2 \\
(1.7)\end{array}$ & $\begin{array}{l}2 \\
(1.7)\end{array}$ & 4.7 \\
\hline $\begin{array}{l}\text { Roasted } \\
\text { cocoyam }\end{array}$ & $\begin{array}{l}24 \\
(20)\end{array}$ & $\begin{array}{l}22 \\
(18.3)\end{array}$ & $\begin{array}{l}12 \\
(10)\end{array}$ & $\begin{array}{l}23 \\
(19.2)\end{array}$ & $\begin{array}{l}39 \\
(32.5)\end{array}$ & 2.7417 \\
\hline $\begin{array}{l}\text { Boiled } \\
\text { cocoyam }\end{array}$ & $\begin{array}{l}20 \\
(16.7)\end{array}$ & $\begin{array}{l}12 \\
(10)\end{array}$ & $\begin{array}{l}22 \\
(18.3)\end{array}$ & $\begin{array}{l}34 \\
(28.3)\end{array}$ & $\begin{array}{l}32 \\
(26.7)\end{array}$ & 2.6167 \\
\hline
\end{tabular}

\section{Source: Field survey, 2019}

(Percentages in parentheses)

The table above presents the result of respondents' frequency of consumption of cocoyam and in what form. The result showed that respondents consumed pounded cocoyam (45.8\%), cocoyam flour $(49.2 \%)$, cocoyam porridge $(45.8 \%)$ and cocoyam soup (80\%) on daily basis. The result also showed that most respondent consumed their cocoyam in form of pounded, Flour, porridge and soup as indicated by mean $(3.9,4.1,4.3$ and 4.7) respectively. This is an indication that cocoyam is an important staple food in the study area. The result also corroborates the assertion of Darkwa and Darkwa(2013) that cocoyam contribute to food security in the lives of many and have rich economic and socio-cultural connotations in Africa. In Togo and elsewhere in Africa, corms are consumed boiled, roasted or fried and are a source of carbohydrate. The high viscosity of some varieties makes them the preferred choice for preparation of pounded fufu, a traditional dish often consumed in West Africa.

Table 2: Respondents' perception of benefits derived from consumption of cocoyam

\begin{tabular}{|c|c|c|c|c|c|c|c|}
\hline $\mathbf{s} / \mathbf{n}$ & Statement & SA & A & UD & D & SD & $\begin{array}{l}\text { Mean } \\
\text { Score }(\bar{x})\end{array}$ \\
\hline I. & $\begin{array}{l}\text { Cocoyam has a lot of } \\
\text { health benefits }\end{array}$ & $\begin{array}{l}66 \\
(55)\end{array}$ & $\begin{array}{l}36 \\
(30)\end{array}$ & $\begin{array}{l}16 \\
(13.4)\end{array}$ & $\begin{array}{l}1 \\
(0.8)\end{array}$ & $\begin{array}{l}1 \\
(0.8)\end{array}$ & 1.6167 \\
\hline II. & $\begin{array}{l}\text { Cocoyam is very } \\
\text { nutritious }\end{array}$ $\quad$. & $\begin{array}{l}52 \\
(43.3)\end{array}$ & $\begin{array}{l}41 \\
(34.2)\end{array}$ & $\begin{array}{l}24 \\
(20.0)\end{array}$ & $\begin{array}{l}1 \\
(0.8)\end{array}$ & $\begin{array}{l}2 \\
(1.7)\end{array}$ & 1.8333 \\
\hline III. & $\begin{array}{l}\text { Cocoyam is good for } \\
\text { people with diabetes }\end{array}$ & 16 & 41 & 47 & 13 & 3 & 2.5500 \\
\hline
\end{tabular}


International Journal of Agriculture, Environment and Bioresearch

Vol. 5, No. 06; 2020

ISSN: $2456-8643$

\begin{tabular}{|c|c|c|c|c|c|c|c|}
\hline & & $(13.3)$ & (34.2) & (39.3) & (10.8) & $(2.5)$ & \\
\hline IV. & $\begin{array}{l}\text { Eating cocoyam can } \\
\text { reduce blood sugar }\end{array}$ & $\begin{array}{l}14 \\
(11.7)\end{array}$ & $\begin{array}{l}47 \\
(39.2)\end{array}$ & $\begin{array}{l}48 \\
(40.0)\end{array}$ & $\begin{array}{l}5 \\
(4.2)\end{array}$ & $\begin{array}{l}6 \\
(5.0)\end{array}$ & 2.5167 \\
\hline V. & $\begin{array}{l}\text { Cocoyam can be used to } \\
\text { prevent heart problems }\end{array}$ & $\begin{array}{l}17 \\
(14.2)\end{array}$ & $\begin{array}{l}38 \\
(31.7)\end{array}$ & $\begin{array}{l}51 \\
(42.5)\end{array}$ & $\begin{array}{l}9 \\
(7.5)\end{array}$ & $\begin{array}{l}5 \\
(4.2)\end{array}$ & 2.5583 \\
\hline VI. & $\begin{array}{l}\text { Cocoyam digests faster } \\
\text { when eaten }\end{array}$ & $\begin{array}{l}20 \\
(16.7)\end{array}$ & $\begin{array}{l}52 \\
(43.3)\end{array}$ & $\begin{array}{l}39 \\
(32.5)\end{array}$ & $\begin{array}{l}6 \\
(5.0)\end{array}$ & $\begin{array}{l}3 \\
(2.5)\end{array}$ & 2.3333 \\
\hline VII. & $\begin{array}{l}\text { Consumption of cocoyam } \\
\text { can reduce blood } \\
\text { pressure }\end{array}$ & $\begin{array}{l}12 \\
(10)\end{array}$ & $\begin{array}{l}35 \\
(29.2)\end{array}$ & $\begin{array}{l}54 \\
(45)\end{array}$ & $\begin{array}{l}14 \\
(11.7)\end{array}$ & $\begin{array}{l}5 \\
(4.2)\end{array}$ & 2.7083 \\
\hline VIII. & $\begin{array}{l}\text { Cocoyam can improve } \\
\text { eye sight }\end{array}$ & $\begin{array}{l}16 \\
(13.3)\end{array}$ & $\begin{array}{l}45 \\
(37.5)\end{array}$ & $\begin{array}{l}48 \\
(40)\end{array}$ & $\begin{array}{l}7 \\
(5.8)\end{array}$ & $\begin{array}{l}4 \\
(3.3)\end{array}$ & 2.4833 \\
\hline IX. & $\begin{array}{l}\text { Cocoyam leaves are good } \\
\text { for vegetables rich in } \\
\text { vitamins. }\end{array}$ & $\begin{array}{l}24 \\
(20)\end{array}$ & $\begin{array}{l}47 \\
(39.2)\end{array}$ & $\begin{array}{l}46 \\
(38.2)\end{array}$ & $\begin{array}{l}1 \\
(0.8)\end{array}$ & $\begin{array}{l}2 \\
(1.7)\end{array}$ & 2.225 \\
\hline X. & $\begin{array}{l}\text { Cocoyam is a cheap } \\
\text { source of carbohydrates } \\
\text { and vitamins }\end{array}$ & $\begin{array}{l}24 \\
(20)\end{array}$ & $\begin{array}{l}45 \\
(37.5)\end{array}$ & $\begin{array}{l}46 \\
(38.3)\end{array}$ & $\begin{array}{l}4 \\
(3.3)\end{array}$ & $\begin{array}{l}1 \\
(0.8)\end{array}$ & 2.25 \\
\hline
\end{tabular}

Source: Field survey, 2019

(Percentages in parentheses)

The table above presents respondents' perception of benefits derived from consumption of cocoyam. The result showed that most respondents perceived cocoyam is good for people with diabetes, reduce blood sugar, prevent heart problem and reduce blood pressure, as indicated by mean $(2.55,2.52,2.56$, and 2.71) respectively. This indicates that rural dwellers perceived that there are health and nutritional benefits to be derived from the consumption of cocoyam. Nutritionally, according to Lyonga and Nzietchueng (1986 cited in Onyeka, 2014) cocoyam has advantages over other root and tuber crops. It has more crude protein than other roots and tubers and its starch is highly digestible because of the small size of the granules. Also, Ojinnakaet al. (2009 cited in Onyeka, 2014) reported that its contents of calcium, phosphorus and vitamins A and B are reasonably higher and these nutritional attributes make it a good base for food preparation for infants. It has been shown that cocoyam starch can be incorporated in the 
Vol. 5, No. 06; 2020

ISSN: $2456-8643$

development of weaning food which is highly digestible and accessible to low-income earners (Oti and Akobundu, 2008 cited in Onyeka, 2014). Although the nutritional advantages highlighted above are not fully known to rural farmers, cocoyam production is an integral part of many smallholder farms in the ecological zones where it is produced in Nigeria.

\section{CONCLUSION AND RECOMMENDATIONS}

The study concluded that though the respondents are aware of the nutritional and medicinal benefits of consumption of cocoyam, there is need for more enlightenment on the level of consumption for various categories of health and nutritional status within households. It was therefore recommended that enlightenment programmes on the consumption of cocoyam should be carried out to ensure that the benefits are efficiently derived.

\section{REFERENCES}

Bamidele, O.P., Ogundele, F.G., Ojubanire, B.A., Fasogbon, M.B. and Bello, O.W. (2014)

Nutritional composition of "gari" analog produced from cassava (Manihotesculenta) and cocoyam (Colocasiaesculenta) tuber. Food Science and Nutrition;2(6): pp706-711.

DOI: 10.1002/fsn3.165.

Bammite, D., Matthews, P.J., Dagnon D.Y., Agbogan, A., Odah, K., Dansi, A. and Tozo, K. (2018) Constraints to production and preferred traits for taro (Colocasiaesculenta) and new cocoyam (Xanthosomamafaffa) in togo, West Africa. African Journal of Food, Agriculture, Nutrition and Development. 18 (2) pp13388-13405 DOI: 10.18697/ajfand.82.17360.

Barbieri, R.L., Costa Gomes, J.C., Alercia, A. and Padulosi, S. (2014) Agricultural biodiversity in Southern Brazil: Integrating efforts for conservation and use of neglected and underutilized species. Sustainability; 6(2): pp741-757. DOI:10.3390/su6020741.

Darkwa, S. and Darkwa, A.A. (2013) Taro (Colocasiaesculenta): It's Utilization in Food

Products in Ghana. Journal of Food Processing and Technology; 4(5): pp1-7. DOI:10.4172/2157-7110.1000225.

Davies, E.M., Labuschagne M.T, Koen E., Benesi I.R.M. and J.Saka, D.K. (2008). Some properties of starches from cocoyam in Malawi. AfricanJournalofFoodScience, 2, pp102-111

Eze, C. C , Korie, O. C., Ben- Chendo, G. N. and Nwaiwu, I. U. (2016). Socio-Economic Effects of Climate Change Variables on Cocoyam Production in Nigeria. Futo Journal Series (FUTOJNLS) eISSN : 2476-8456 p-ISSN : 2467-8325 Volume-2, Issue-2, pp- 210 - 235 www.futojnls.org Igbabul, B.D., Amove, J. and Twadue, I. (2014) Effect of fermentation on the proximate composition, antinutritional factors and functional properties of cocoyam (Colocasiaesculenta) flour. African Journal of Food Science and Technology; 5: pp67-74. DOI: http:/dx.doi.org/10.14303/ajfst.2014.016.

Jane J., Shen L., Lim S., Kasemsuwantt T. and Nip, W.K. (1992) Physical and chemical studies of taro starches and flours. Cereal Chemistry; 69(5): pp528-535.Lebot, V. (2009). Tropical root and tuber crops: cassava, sweet potato, yams and aroids. Pests and diseases. Pp. 253-264. Crop production science in horticulture series; Wallingford, UK: CAB International Magbagbeola, J.A.O., Adetoso, J.A. and Owolabi O.A. (2010)Neglected and underutilized species (NUS): a panacea for community focused development to poverty alleviation/poverty reduction in Nigeria. Journal of Economics and InternationalFinance; 2(10): pp208-211. 
Manner, H.I. \& Taylor, M. (2010). FARM and Forestry Production and Marketing Profile for Taro (colocasiaesculenta). In Elevitch, C.R. (ed), Specialty crops for pacific island agroforestry, permanent agriculture resources (PAR), Holualoa, Hawaii. Http://agroforestory.net/scps. Onyeka, J. 2014. Status of Cocoyam (Colocasiaesculentaand Xanthosomaspp) in West and Central Africa: Production, Household Importance and the Threat from Leaf Blight. Lima (Peru). CGIAR Research Program on Roots, Tubers and Bananas (RTB). Available online at: www.rtb.cgiar.org 